\author{
RENATA RASZEWSKA-SKAŁECKA \\ ORCID: 0000-0001-7467-5703 \\ Uniwersytet Wrocławski \\ Instytut Nauk Administracyjnych \\ Zakład Ustroju Administracji Publicznej
}

\title{
WYBRANE ŹRÓDŁA PRAWA ZAKŁADOWEGO I ROLA WŁADZTWA ZAKŁADOWEGO WOBEC UŻYTKOWNIKA ZAKŁADU ADMINISTRACYJNEGO
}

\begin{abstract}
Abstrakt: W artykule przedstawiono ewolucję koncepcji władztwa zakładowego i prawa zakładowego w sferze działania zakładu administracyjnego. Celem analizy jest wskazanie, przy pomocy jakich prawnych form działania administracji publicznej kształtowany jest status prawny użytkownika zakładu w sferze działania szkoły. Problematyka podejmowana w opracowaniu podzielona jest na trzy części: 1) reinterpretacja władztwa zakładowego w nauce prawa administracyjnego i w orzecznictwie sądowym, 2) prawne formy działania organów zakładu administracyjnego i władztwo zakładowe w sferze działania szkoły, 3) wygaśnięcie prawa do korzystania ze świadczeń zakładowych jako przejaw władztwa zakładowego.
\end{abstract}

Słowa kluczowe: zakład administracyjny, źródła prawa, władztwo zakładowe

\section{UWAGI OGÓLNE}

W niniejszych rozważaniach zaprezentowano koncepcję władztwa zakładowego i prawa zakładowego w sferze działania wybranego zakładu administracyjnego. Celem analizy jest ukazanie, przy pomocy jakich prawnych form działania administracji publicznej kształtowany jest status prawny użytkownika zakładu. Można przyjąć, że zakres władztwa zakładowego wynika z zadań przypisanych danemu typowi zakładu administracyjnego i prawnych form działania władz zakładowych wobec użytkownika zakładu oraz innych osób, które znalazły się w sferze działania danego zakładu.

Zakład administracyjny posiada ustawowe uprawnienia do kreowania sytuacji użytkownika zakładu — na przykład uczelnia publiczna może skreślić jej użytkownika w obliczu zaistnienia przesłanek określonych przez ustawę i przepisy we- 
wnątrzzakładowe szkoły, stanowione na podstawie delegacji ustawowej. Zadania zakładu administracyjnego określa porządek prawny i to on przyznaje organom zakładu administracyjnoprawne formy działania ${ }^{1}$. Statut i regulamin zakładu administracyjnego jako źródła prawa zakładowego nie tylko odgrywają znaczącą rolę w organizacji i funkcjonowaniu zakładu, ale też mają doniosły wpływ na zakres i sposób realizowania władztwa zakładowego organów zakładu wobec użytkownika. Źródłami prawa zakładowego są statuty i regulaminy, uchwały organów kolegialnych czy zarządzenia organów monokratycznych. Akty te kreują prawa i obowiązki osób znajdujących się w zależności zakładowej, służbowej lub organizacyjnej od organów je wydających, a nie prawa i obowiązki obywateli ${ }^{2}$. Statut szkoły czy regulamin studiów mogą stanowić podstawę wydawanych aktów wewnątrzzakładowych w indywidualnych sprawach użytkownika. Prawne spojrzenie na statuty i regulaminy jako podstawowe formy prawa zakładowego wskazuje, że są to akty prawne różniące się sposobem i trybem stanowienia, zakresem obowiązywania (przedmiotem regulacji), miejscem i charakterem prawnym w systemie źródeł prawa. Statut i regulamin zakładu są aktami normatywnymi prawa zakładowego, rodzą stosunki prawne i mogą być podstawą aktów zakładowych ${ }^{3}$.

W pierwszej kolejności należy przyjrzeć się reinterpretacji władztwa zakładowego w zakładzie, by określić zakres i sposób jego realizowania przez organy zakładu na podstawie źródeł prawa zakładowego. Między zakładem a jego użytkownikiem nawiązuje się stosunek administracyjnoprawny i wytwarza stosunek władztwa zakładowego. Korzystanie z zakładów jest ograniczone do konkretnej grupy użytkowników zakładu, jego dostępność może zaś być mniej lub bardziej powszechna ${ }^{4}$. Zakład ma wobec swoich użytkowników uprawnienia zwierzchnie — tak zwane władztwo zakładowe ${ }^{5}$. W okresie dwudziestolecia międzywojennego Tadeusz Bigo stwierdził, że zakład publiczny rozporządza środkami szczególnymi, które określa się mianem władztwa zakładowego i policji zakładowej. Władztwo zakładowe według autora polega na jednostronnym regulowaniu stosunku użytkowania (a więc w stosunku do destynatariusza) i w tym przypadku, podobnie jak w wypadku policji zakładowej, zakład używa bezpośredniego przymusu ad-

1 J. Filipek, Prawo administracyjne. Instytucje ogólne, cz. 1, Kraków 1995, s. 167; por. A. Bednarczyk, Zależność zakładowa, [w:] Prawo administracyjne w mechanizmie prawa, red. J. Filipek, Kraków 2012, s. 35.

2 A. Bednarczyk, op. cit., s. 39.

3 R. Raszewska-Skałecka, Statut i regulamin zakładu administracyjnego jako źródła prawa, Wrocław 2007; eadem, Miejsce statutu i regulaminu zakładu administracyjnego w systemie źródet prawa. Kwestie prawne, „Przegląd Prawa i Administracji” 77, 2008, s. 259-291.

${ }^{4}$ R. Raszewska-Skałecka, Koncepcja zakładu administracyjnego $w$ polskiej nauce prawa administracyjnego, „Przegląd Prawa i Administracji” 68, 2005, s. 181-225.

5 H. Izdebski, M. Kulesza, Administracja publiczna. Zagadnienia ogólne, wyd. 2, Warszawa 1999, s. 110-111. 
ministracyjnego ${ }^{6}$. T. Bigo uznał władztwo zakładowe za formę korzystania przez zakład z bezpośredniego przymusu administracyjnego, wyróżniając przy tym instytucję policji zakładowej, która miała zapewnić prawidłowe funkcjonowanie zakładu pod względem porządku i organizacji. Częścią władztwa zakładowego przypisanego organom zakładu jest władztwo porządkowe. Rozciąga się ono nie tylko na użytkowników, ale także na osoby, które znalazły się w sferze działania zakładu. Władztwo porządkowe T. Bigo nazywa policją zakładową, definiując ją jako jednostronne regulowanie stosunku zakładu do osób trzecich. Wskazał, że policja zakładowa wyraża się $\mathrm{z}$ reguły $\mathrm{w}$ aktach o treści negatywnej, mających na celu usuwanie wszystkiego, co mogłoby być przeszkodą w normalnym funkcjonowaniu zakładu, a jej elementem jest używanie administracyjnego przymusu bezpośredniego ${ }^{7}$. Stwierdzenie autora, że częścią władztwa zakładowego przypisanego organom zakładu jest władztwo porządkowe, rozciągające się nie tylko na użytkowników, ale także na osoby, które znalazły się w sferze działania zakładu, znajduje kontynuację w doktrynie ${ }^{8}$. Z reguły władztwo zakładowe ,zdeterminowane jest bezpośrednio przez treść i zakres uprawnień, jakie przysługują organom zakładu w stosunku do jego użytkowników ze względu na zadania, które zakład ma realizować. Natomiast władztwo porządkowe, jakkolwiek służy ono także realizacji zadań zakładu, ma zapewnić generalnie funkcjonowanie zakładu”9. Niewątpliwie „władztwo porządkowe służy również ochronie zakładu przed jednostką, tak użytkownikiem, jak i innymi osobami, które zakłócają jego funkcjonowanie"10. Należy zaznaczyć, że charakter i przeznaczenie opracowania nie pozwalają na kompleksową analizę zaproponowanego tematu badawczego.

\section{W KWESTII REINTERPRETACJI WŁADZTWA ZAKŁADOWEGO W NAUCE PRAWA ADMINISTRACYJNEGO}

W rozwoju myśli prawniczej w połączeniu nauki prawa administracyjnego z prawem szkolnym i systemem oświaty nie bez znaczenia są dokonania Janusza Homplewicza, według którego „zakład” to podstawowe ogniwo całego systemu oświaty i jego organizacji. Zakładem określa on

jednostkę organizacyjną świadczącą określone usługi na rzecz swych użytkowników, w oparciu o posiadane władztwo zakładowe (regulowane zarządzeniami, regulaminami i statutem) i zakładowe (z tymi użytkownikami - uczniami, wychowankami) stosunki prawne. [...] Szkoły i inne pla-

${ }^{6}$ T. Bigo, Zwiazki publiczno-prawne w świetle ustawodawstwa polskiego, Warszawa 1928, s. 200.

7 Ibidem.

${ }^{8}$ Zob. K. Klonowski, Władztwo zakładowe, [w:] Władztwo administracyjne. Administracja publiczna w sferze imperium $i$ w sferze dominium, red. J. Łukaszewicz, Rzeszów 2012, s. 248-249.

9 J. Filipek, op. cit., s. 175.

10 K. Klonowski, op. cit., s. 250. 
cówki oświatowo-wychowawcze są po prostu zakładami w prawniczym tego pojęcia znaczeniu, tj. jednostkami organizacyjnymi świadczącymi ze swej istoty pewne usługi na rzecz określonych użytkowników, uczniów, wychowanków ${ }^{11}$.

Autor rozwijał problematykę zakładów administracyjnych na gruncie zwłaszcza zakładów oświatowych ${ }^{12}$. Prawo szkolne, w jego prawniczym wątku problemowym, skorzystało z rozwiniętej w nauce prawa administracyjnego dyskusji nad pojęciem i sytuacją prawną „zakładu administracyjnego"13, w tym szkół i innych placówek oświatowo-wychowawczych. Mimo upływu lat polemika ta nie ustaje w dyskursie naukowym. Z prawniczej dyskusji o zakładach J. Homplewicz zaczerpnął ten jej wątek, w którym wykazywano, że istotnym kryterium zakładu jest istnienie odrębnych stosunków prawnych z użytkownikami (T. Bigo, E. Ochendowski), stosunków opartych na władztwie zakładowym rozumianym prawnie ${ }^{14}$. Uznał on, że zakład jest ,jednostką organizacyjną aparatu państwowego, niekiedy oddzielną osobą prawną, realizującą określone zadania (na przykład oświatowe) na podstawie przyznanych jej kompetencji oraz środków osobowych (kadra) i rzeczowych (wyposażenie). $\mathrm{Z}$ zakładem jest też związane władztwo zakładowe wobec użytkowników"15.

J. Homplewicz określił zakład administracyjny w znaczeniu prawnym jako

instytucję, realizującą pewne, z reguły niegospodarcze zadania czy usługi na rzecz pewnej grupy, prawnie określonych swych użytkowników. Zakładowi takiemu obowiązujący system prawny określa zadania i funkcje; ma on wtedy obowiązek prawny działać na rzecz swych użytkowników. Działanie zakładu dla użytkowników związanych z danym zakładem, na zasadzie stosunku administracyjnoprawnego (stosunki zakładowe), odróżnia go od innych kategorii jednostek aparatu administracyjnego ${ }^{16}$.

Autor podkreśla, że „sposób korzystania z takiego zakładu jest publiczno-prawny, oparty na stosunku administracyjno-prawnym i na owym władztwie zakładowym, a nie na cywilno-prawnej umowie usługi czy użytkowania"17. Z kolei zakła-

11 J. Homplewicz, Zagadnienia ustawodawstwa szkolnego (Zarys problematyki polskiego prawa szkolnego), Katowice 1973, s. 45; idem, Szkoły i placówki oświatowo-wychowawcze w systemie administracji państwowej, „Zeszyty Naukowe UJ. Prace Prawnicze” 1966, z. 25, s. 234-237.

12 J. Homplewicz, Polskie prawo szkolne. Zagadnienia podstawowe, Warszawa 1984, s. 162 n.

13 Zob. idem, Tradycyjne a wspótczesne instytucje prawa szkolnego (Studium z zakresu nauki prawa administracyjnego), ,Zeszyty Naukowe UJ. Prace Prawnicze” 1985, z. 112, s. 25.

14 Ibidem, s. 26; por. T. Bigo, op. cit.; E. Ochendowski, Zakład administracyjny jako podmiot administracji państwowej, Poznań 1969.

15 J. Homplewicz, Polskie prawo szkolne..., s. 163.

16 J. Homplewicz, Zagadnienia prawne działalności opiekuńczo-wychowawczej, Rzeszów 1989, s. 60 .

17 J. Homplewicz, Polskie prawo szkolne..., s. 162-163; idem, Tradycyjne a wspótczesne instytucje prawa szkolnego..., s. 25; zob. na ten temat: P. Lisowski, Szkoła samorzadowa jako zakład administracyjny, Wrocław 1997, s. 134 (niepubl.); idem, Relacje strukturalne w polskim samorzadzie terytorialnym, Wrocław 2013, s. 176 n.; R. Raszewska-Skałecka, Statut i regulamin zakładu administracyjnego jako źródła prawa..., s. 39 n.; eadem, Koncepcja zakładu administracyjnego 
dowe stosunki prawne, powstające pomiędzy zakładem a jego użytkownikiem na tle korzystania z takiego zakładu, są kształtowane w ramach całego systemu obowiązującego prawa, w tym zwłaszcza przepisów prawa administracyjnego i wynikających $\mathrm{z}$ aktów prawa zakładowego ${ }^{18}$. To otwiera drogę do stwierdzenia, że

w prawie szkolnym ów użytkownik zakładu (uczeń) uzyskuje swą własną pozycję prawną w stosunkach z organami szkoły. Zadaniem szkoły zaczyna być nawet nie tyle sprawowanie władztwa wobec ucznia, ile realizacja obowiązujących przepisów szkolnych poprzez nawiązywanie owych stosunków szkolnoprawnych z uczniem jako ich podmiotem, choć tym samym i użytkownikiem zakładu $^{19}$.

W zakładzie administracyjnym wyodrębnia się władztwo porządkowe (zwane organizacyjnym), w ramach którego podejmowane są działania mające stanowić gwarancję normalnego jego funkcjonowania. W kategorii szkół i innych zakładów oświatowo-wychowawczych J. Homplewicz wyodrębnia tak zwane władztwo pedagogiczne dotyczące procesów wychowawczych, będące specjalnym rodzajem, formą występującego władztwa zakładowego, obejmujące prawo wydawania wychowawczych i dydaktycznych poleceń i zarządzeń ${ }^{20}$. Władztwo pedagogiczne jest wykonywane nie tylko przez organy zakładu, ale także przez wszystkich pracowników pedagogicznych zakładu, którzy

stosownie do przydziału ich funkcji - realizując prawem określone i nakazane zadania danej szkoły czy też zakładu wychowawczego - wykonują to władztwo pedagogiczne wobec swych uczniów i wychowanków. A zatem, władztwo to obejmuje całą sferę autorytatywnej czy też wiążącej działalności organów i pedagogicznych pracowników zakładu, rozwijanej wobec uczniów

w polskiej nauce prawa administracyjnego..., s. 181-225; P. Chmielnicki, Zakłady administracyjne w Polsce. Ustrój wewnętrzny, Warszawa 2008, s. 42-70; Z. Czarnik, J. Posłuszny, Zakład publiczny, [w:] System prawa administracyjnego. Podmioty administrujace, red. R. Hauser, Z. Niewiadomski, A. Wróbel, t. 6, Warszawa 2011, s. 440-458.

18 Zob. P. Lisowski, Z problematyki postępowania administracyjnego na forum szkoły samorzadowej, [w:] Nauka administracji wobec wyzwań współczesnego państwa prawa, red. J. Łukaszewicz, Rzeszów 2002, s. 338; idem, Prawo zakładowe - in rebus angustis? (wybrane problemy administracyjnoprawne), „Przegląd Prawa i Administracji” C/1, 2015, s. 207-219. Cechą charakterystyczną norm prawa zakładowego jest to, że „obowiązują tylko w relacjach z danym zakładem administracyjnym i — nie będąc normami powszechnie obowiązującymi — są normami wewnętrznego obowiązywania (w stosunku do użytkowników zakładu — na przykład regulamin studiów) lub normami o charakterze powszechnie obowiązującym (względem osób aplikujących do przyjęcia w poczet destynatariuszy danego zakładu — na przykład zasady rekrutacji na studia) czy też normami kierownictwa wewnętrznego" — ibidem, s. 209.

19 J. Homplewicz, Tradycyjne a wspótczesne instytucje prawa szkolnego..., s. 38.

20 J. Homplewicz, Szkoły i placówki oświatowo-wychowawcze w systemie administracji państwowej..., s. 234-235; idem, Polskie prawo szkolne..., s. 170-171; zob. E. Ochendowski, op. cit., s. 177; P. Przybysz, Sytuacja prawna jednostki w zaktadzie oświatowym, [w:] Jednostka wobec działań administracji publicznej, red. E. Ura, Rzeszów 2001, s. 376; K. Klonowski, Ochrona praw użytkownika zakładu publicznego, [w:] Instytucje wspótczesnego prawa administracyjnego. Księga jubileuszowa Profesora zw. dra hab. Józefa Filipka, red. I. Skrzydło-Niżnik et al., Kraków 2001, s. 348-349. 
i wychowanków - i to działalności władczej wynikającej z samej istoty procesów wychowywania i nauczania i wyłącznie charakterem tych procesów uzasadnionej ${ }^{21}$.

Można sądzić, iż granice władztwa zakładowego wyznaczone są przez cel zakładu oraz przez prawa przysługujące użytkownikom zakładu — władztwo zakładowe powinno być wykorzystywane tylko do osiągnięcia celów zakładu, dlatego jego zakres jest zależny od typu zakładu oraz rodzaju i celu prowadzonej działalności.

Nie ulega wątpliwości, że ustawa reguluje z zasady tylko zadania zakładu. Inne materie zależności zakładowej zdaniem Józefa Filipka

regulują w przeważającej mierze normy zawarte w źródłach prawa niższego szczebla. Sama ustawa tylko wyjątkowo reguluje określone czynności zakładu, postępowanie — jakie mają prowadzić jego organy albo szczegółowe prawa lub obowiązki jego użytkowników. [...] Trzeba dedukować z ustawowej regulacji zadań zakładu, jakie czynności — w tym, jakie czynności prawne — organy zakładu mogą lub powinny przedsiębrać w stosunku do użytkowników zakładu. To samo odnosi się do wszelkiego ograniczania praw użytkowników zakładu lub nakładania na nich obowiązków oraz określania trybu działania zakładu 22 .

A to oznacza, że prawidłową działalność danego typu zakładu administracyjnego zapewnia władztwo zakładowe,

wykonywane przez organa zakładu w stosunku do użytkowników i wraz ze wszystkimi występującymi tu jego ograniczeniami pojmowane być przecież może jako forma i część władztwa państwowego, realizowanego w zakładach jako jednostkach aparatu administracji państwowej. [...] Władztwo to nie może być przeciwstawiane pojęciowo władztwu ogólnopaństwowemu, bowiem jest mu podporządkowane. Mało, wynika nawet z tego władztwa ogólnego, tak że czynności samego władztwa zakładowego na zewnątrz nawet zarachowuje na siebie (odpowiada za nie) kierownik zakładu jako za działalność własną i jednocześnie władczą działalność organu państwowego ${ }^{23}$.

Władztwo zakładowe postrzegane jest w nauce prawa niejednoznacznie i, jak to czasami bywa w doktrynie, opisanie i nazwanie badanego zjawiska prawnego nastręczać może trudności. T. Bigo zainicjował pogląd, że władztwo zakładowe jest formą władztwa państwowego (administracyjnego) ${ }^{24}$. Z kolei Eugeniusz Ochendowski przyjął za Jerzym Starościakiem, że

istotę władztwa zakładowego stanowi zakres upoważnień organów zakładu do jednostronnego kształtowania stosunków prawnych z użytkownikami i osobami, które znalazły się na terenie zakładu nawet w innym charakterze (na przykład jako osoby odwiedzające chorych w szpitalu). To władztwo uważa się za część władztwa państwowego. To ostatnie warunkuje występowanie władztwa zakładowego ${ }^{25}$.

21 J. Homplewicz, Prawne formy działania władz szkolnych, „Chowanna” 1972, z. 1, s. 16.

22 J. Filipek, op. cit., s. 172-173.

23 J. Homplewicz, Szkoły i placówki oświatowo-wychowawcze w systemie administracji państwowej..., s. 233-234.

24 E. Ochendowski, op. cit., s. 170 n.; idem, Koncepcja szczególnych stosunków władczych i jej rola, [w:] Studia z dziedziny prawa administracyjnego, red. L. Bar, Wrocław 1971, s. 43 n.

25 E. Ochendowski, Zakład administracyjny jako podmiot administracji państwowej..., s. 175. 


\section{Autor stwierdził, że}

władztwo zakładowe, jako ogół uprawnień organów zakładu wobec jego użytkowników, wynika z samego charakteru prawnego zakładu administracyjnego i jego działalności. Treść tego władztwa określają regulaminy i statuty zakładów administracyjnych. Dzięki wyposażeniu we władztwo organy zakładów podejmują akty zakładowe, polegające na prawnej możliwości wydawania poleceń użytkownikom, i mogą stosować wobec użytkowników środki przymusu w celu zapewnienia prawidłowego funkcjonowania zakładu. Te akty zakładowe muszą być wykonywane pod rygorem zastosowania sankcji wobec użytkownika aż do wykluczenia danej osoby z grona użytkowników danego zakładu, jeżeli nie ma obowiązku prawnego korzystania z danego zakładu ${ }^{26}$.

E. Ochendowski rozumie przez władztwo zakładowe zarówno władztwo sensu stricto, to jest nad użytkownikami zakładu, jak i tak zwaną policję zakładową nad osobami trzecimi.

Niewątpliwie zależność zakładowa i władztwo zakładowe są z sobą ściśle powiązane i odpowiadają sobie wzajemnie ${ }^{27}$. Im szerszy jest zakres zależności zakładowej, tym szerszy jest zakres władztwa zakładowego ${ }^{28}$. Prawo zakładowe zdaniem J. Filipka

przyznaje organom zakładu szczególne władztwo porządkowe, któremu obok użytkowników zakładu podlegają także inne osoby, nawet gdy tylko przypadkowo znalazły się w zasięgu działalności zakładu. [...] ma zapewnić, aby działalność zakładu mogła być faktycznie przeprowadzona przy ewentualnym zastosowaniu autorytatywnych form działania wobec każdego, kto ją utrudnia lub uniemożliwia ${ }^{29}$.

\section{Według Piotra Lisowskiego ${ }^{30}$}

władztwo zakładowe nie jest tożsame $\mathrm{z}$ władztwem administracyjnym, a to ze względu na specyficzne (o wewnętrznej prowieniencji) uwarunkowania podmiotowo-przedmiotowe. Władztwo zakładowe w swoim podstawowym zakresie dotyczy użytkowników (czasami nawet poza terenem zakładu - dyscyplina zakładowa). Czasami dotyczy również osób trzecich (władztwo porządkowe - policja zakładowa). Niekiedy odnosi się tylko do pracowników zakładu (władztwo służbowe). W każdym z tych układów determinowane jest pierwotnie i przede wszystkim celami zakładu. Ta specjalizacja przedmiotowa preferuje wymuszanie posłuszeństwa głównie przy pomocy środków dyscypliny zakładowej (o wewnętrznym charakterze) $)^{31}$.

${ }^{26}$ E. Ochendowski, Organy administracji niezespolonej i zaktady administracyjne, [w:] System prawa administracyjnego, t. 2, red. J. Jendrośka, Wrocław 1977, s. 344-345.

27 „Pomiędzy studentem a uczelnią wyższą, w której on studiuje, zachodzi prawny stosunek zakładowy, student podlega władztwu zakładowemu uczelni — uczelnia jest zakładem administracyjnym, a student zaś jego użytkownikiem. Akty prawne organów uczelni dotyczące przyznania, nieprzyznania lub cofnięcia stypendium socjalnego swemu studentowi są zatem przejawami władztwa zakładowego i stosunków zakładowych w uczelni" (postanowienie NSA z dnia 16 kwietnia 1987 roku, ISA 448/87, OSP 1988/10/223).

28 J. Filipek, op. cit., s. 175.

${ }^{29}$ Ibidem.

${ }^{30}$ P. Lisowski, Szkoła samorządowa jako zakład administracyjny..., s. 134.

31 Do typowych sankcji dyscyplinarnych należą: kary pieniężne, wstrzymanie świadczeń, utrata uiszczonych opłat, zwiększenie opłat, zmniejszenie zakresu świadczeń, pozbawienie statusu użytkownika (przy zakładach dobrowolnych). 
Zakłady administracyjne, co do zasady, w swojej podstawowej działalności nie posługują się środkami powszechnej egzekucji administracyjnej ${ }^{32}$. Według J. Filipka stosunek zależności zakładowej musi być odróżniany od stosunków administracyjnoprawnych charakterystycznych dla ogólnie obowiązującego prawa. Służy on

świadomej działalności świadczeniowej, dla której [...] przede wszystkim jej cel otrzymuje ustawowo uregulowaną podstawę prawną. I z tego względu towarzyszy stosunkowi zależności zakładowej szczególny rodzaj władztwa przekraczającego ramy władztwa przyjmowane w typowych stosunkach administracyjnoprawnych, które występują w obrębie ogólnie obowiązującego prawa administracyjnego ${ }^{33}$.

W ocenie P. Lisowskiego ,uzasadnionym [...] wydaje się nie tyle rozłączne traktowanie władztwa zakładowego i powszechnego, co uznanie tego pierwszego za odmianę władztwa administracyjnego" 34 .

Jan Boć35 stwierdza, że „między korzystającym a organami zakładu wytwarza się z mocy prawa lub decyzji o przyjęciu stosunek władztwa zakładowego, którego treść stanowi z jednej strony możność jednostronnego ustalania pozycji prawnej i faktycznej użytkownika, z drugiej zaś obowiązek użytkownika poddania się dyspozycjom organów zakładu". Podstawa prawna dla władztwa zakładowego zdaniem autora ,jest w pewnym stopniu swobodna wobec porządku prawnego powszechnego. Obejmuje ona także akty normatywne typu statutów, regulaminów i zarządzeń, zgodne co do treści z ogólnie obowiązującym prawem, ale skierowane do ograniczonego kręgu adresatów" ${ }^{36}$. Przyjmuje się, że zagwarantowanie wykonania aktów prawnych organów zakładu jest dwojakie: 1) w sytuacji korzystania dobrowolnego głównym środkiem jest usunięcie z grona użytkowników, 2) w sytuacji korzystania przymusowego - możność użycia środka przymusu państwowego, najczęściej przez organy zakładu. Podległością organom zakładu objęte są również na terenie zakładu osoby niebędące jego użytkownikami ${ }^{37}$.

Władztwo zakładowe wynika z upoważnień organów zakładu do abstrakcyjnych, jak również konkretnych regulacji na podstawie i w ramach ustaw; powinno być wykorzystywane tylko do osiągnięcia wyznaczonych przez normy prawne

32 J. Filipek twierdzi, że wobec użytkowników mogą być stosowane tylko środki dyscyplinarne - wewnątrzzakładowe. Jakie środki dyscyplinarne mogą być stosowane w różnych rodzajach zakładów administracyjnych i zakres ich stosowania zależą od specyfiki zakładu zdeterminowanej jego zadaniami i dyscypliny, jaka musi panować w zakładzie administracyjnym (op. cit., s. 175).

33 Ibidem, s. 173. „Zakres tego władztwa i sposób jego wykonywania nie są jednakowe dla wszystkich zakładów. W zależności od zakładu może on być węższy lub szerszy i różne formy lub środki działania, a także różne sposoby działania mogą być nim objęte".

34 P. Lisowski, Szkoła samorzadowa jako zakład administracyjny..., s. 135-136.

35 Prawa administracyjne, red. J. Boć, Wrocław 2007, s. 163.

36 Ibidem.

37 Ibidem. 
celów zakładu ${ }^{38}$. W ramach władztwa zakładowego w oparciu o kryterium adresata można wyodrębnićc ${ }^{39}:$ 1) uprawnienia władcze w stosunku do użytkowników znajdujących się na terenie zakładu; 2) uprawnienia władcze w stosunku do użytkowników znajdujących się poza obrębem zakładu; 3) uprawnienia władcze w stosunku do osób niebędących użytkownikami zakładu, a które znalazły się na terenie zakładu. Zakres władztwa zakładowego może być większy lub mniejszy. Mając to na uwadze, zdaniem E. Ochendowskiego można mówić o władztwie zakładowym obejmującym prawo do stanowienia norm ogólnych (abstrakcyjnych) i norm indywidualnych (konkretnych) oraz o władztwie zakładowym obejmującym uprawnienie do stanowienia tylko norm indywidualnych. Uznał on, że władztwo zakładowe jest częścią władztwa państwowego i powinno być wykorzystywane tylko do osiągnięcia celów zakładu ${ }^{40}$. Przedstawione poglądy pozwalają wyróżnić41: 1) władztwo zakładowe ,pełne”, obejmujące upoważnienie do stanowienia norm ogólnych (statutów i regulaminów zakładowych) i norm indywidualnych; 2) władztwo zakładowe „ograniczone”, obejmujące tylko upoważnienie do stanowienia aktów niższego rzędu niż statuty i regulaminy zakładowe; 3) stosując kryterium adresata - uprawnienia władcze, o których mowa powyżej.

Jan Zimmermann ${ }^{42}$ również przyjął, że władztwo zakładowe stanowi wycinek władztwa państwowego, który został przypisany zakładom publicznym, a jego odbiciem jest zależność zakładowa. Autor wskazuje, że zakłady administracyjne (zakłady publiczne) są związane z państwem $\mathrm{i}$ ich istnienie zależy od państwa, nawet gdy są tworzone przez podmioty niepaństwowe. Władztwo zakładowe dotyczy przede wszystkim podmiotów, które korzystają z usług zakładu, choć wyjątkowo władztwo to rozciąga się na osoby trzecie (na przykład osoby niebędące studentami, a uczestniczące w otwartym wykładzie). Istota władztwa zakładowego według autora polega na tym, że organy zakładu administracyjnego mają prawo do jednostronnego, elastycznego i dość swobodnego kształtowania uprawnień lub obowiązków użytkowników zakładu, oczywiście tylko w zakresie odpowiadającym celom działania danego zakładu. Istotą zależności zakładowej jest to, że użytkownik zakładu poddaje się dobrowolnie lub jest poddawany szczególnemu reżimowi prawnemu wiążącemu się z celem działania danego zakładu. Stosunki prawne, jakie tu powstają, ,nakładają się" na wszelkie inne stosunki prawne łączące daną osobę z państwem i z tego powodu bywają nazywane „,szczególnymi stosunkami władczymi”. Wynikają one bezpośrednio z ustawy, z mocy decyzji administracyjnej, z samej czynności podjętej przez przyszłego użytkownika lub wyjątkowo

38 K. Klonowski, Ochrona praw użytkownika zakładu publicznego..., s. 348.

39 E. Ochendowski, Organy administracji niezespolonej i zakłady administracyjne..., s. 346;

por. K. Klonowski, Ochrona praw użytkownika zakładu publicznego..., s. 348.

40 E. Ochendowski, Prawo administracyjne. Część ogólna, Toruń 2001, s. 234 n.

${ }^{41}$ P. Chmielnicki, op. cit., s. 64, za: E. Ochendowski, Zaklad administracyjny jako podmiot administracji państwowej..., s. 175 i 178.

42 J. Zimmermann, Prawo administracyjne, Warszawa 2018, s. 204-205. 
także z mocy wyroku sądowego. Podlegający władztwu użytkownik jest związany obowiązkami wynikającymi z aktów zakładowych, a za ich nieprzestrzeganie podlega odpowiedzialności dyscyplinarnej. Co ważne, użytkownik realizuje swoje prawa i w tym zakresie jest poddany szczególnej ochronie. J. Zimmermann wyróżnia dwa rodzaje władztwa zakładowego: władztwo administracyjne i władztwo fachowe. Pierwsze dotyczy kwestii podstawowych, związanych z samym funkcjonowaniem zakładu, jego organizacją i techniką świadczenia usług. Realizacja tego władztwa leży w kompetencjach organów zakładu. Drugi rodzaj wiąże się z merytoryczną istotą świadczonych usług i służy pracownikom zakładu, którzy przy jego realizacji wykorzystują swoją wiedzę fachową ${ }^{43}$. Wydaje się, że w ramach wyodrębnionego tu władztwa fachowego można dostrzec podobieństwo do wydzielonego władztwa pedagogicznego w szkolnictwie.

Należy zauważyć, że zakres władztwa zakładowego jest funkcją zadań przypisanych prawem danemu typowi zakładów administracyjnych. Na władztwo zakładowe składają się kompetencje do ${ }^{44}$ :

1) tworzenia wewnątrzzakładowych norm ogólnych; 2) konkretyzacji prawa w drodze decyzji i innych aktów indywidualnych skierowanych do użytkowników oraz innych osób, które znalazły się na terenie zakładu, a wydawanych na podstawie przepisów prawa powszechnie obowiązującego oraz aktów prawa zakładowego (w przypadku decyzji wydawanych na podstawie przepisów rangi ustawowej a uszczegóławianych jedynie w zakresie podstawy przepisami zawartymi w aktach podustawowych i aktach prawa zakładowego); 3) egzekwowania wskazanych wyżej aktów, i w tym mieści się również kompetencja do stosowania środków przymusu bezpośredniego; 4) upoważniania pracowników do dysponowania poszczególnymi kompetencjami, które składają się na całość władztwa danego organu zakładu; 5) nawiązywania i rozwiązywania stosunków zależności zakładowej z jego użytkownikami z wyłączeniem sytuacji, kiedy dla tych działań organów zakładu ustawodawca narzucił wymóg stosowania formy decyzji administracyjnej.

W nauce prawa administracyjnego pojęcie prawa zakładowego nie uzyskało tak szerokiej akceptacji, jak pojęcie władztwa zakładowego. Być może wynika to z charakteru władztwa zakładowego, który w doktrynie jest dyskusyjny. Wśród przedstawicieli nauki są tacy, którzy opowiadają się za uznaniem go za rodzaj władztwa państwowego, i tacy, którzy przyjmują, że to władztwo wynika z istoty zakładu $^{45}$. Warte przedstawienia $\mathrm{w}$ tym miejscu są tezy o uniwersalności prawa zakładowego Jerzego S. Langroda ${ }^{46}$, według którego prawo zakładowe związane jest z instytucją zakładu administracyjnego, jednak nie wykluczył on możliwości jego występowania w przypadku innych instytucji administrujących. Prawo

43 Ibidem, s. 205.

44 K. Klonowski, Władztwo zakładowe..., s. 245.

45 Zob. M. Wierzbowski, A. Wierzbowska, Zakład administracyjny, [w:] Prawo administracyjne, red. J. Jagielski, M. Wierzbowski, Warszawa 2019, s. 175.

46 J.S. Langrod, Instytucje prawa administracyjnego. Zarys części ogólnej. Reprint, Kraków 2003, s. 393; por. T. Brzezicki, B. Chudziński, Aktualność koncepcji „prawa zakładowego” na przykładzie szkoty wyższej, [w:] Teoria instytucji prawa administracyjnego. Księga pamiatkowa Profesora Jerzego Stefana Langroda, red. J. Niczyporuk, Paryż-Lublin 2011, s. 51-59. 
zakładowe nie jest samoistnym bytem związanym z istotą zakładu, lecz istnieje w oparciu o wolę ustawodawcy kreującą zakład. Cechami charakterystycznymi prawa zakładowego są $\left.{ }^{47}: 1\right)$ szeroki zakres swobody zakładu w granicach reglamentacji prawnej - uregulowanej aktualnie w przepisach konstytucji, a zwłaszcza przepisach rangi ustawowej; 2) szeroki zasięg aktywności „rozkazodawczej” — podmiotowo zakres władzy „rozkazodawczej” zakładu rozciąga się na krąg osób, które poddane są trwale lub przejściowo władzy zakładu, przedmiotowo zaś rozciąga się dalej, niż na to pozwala cel zakładu, a nawet przekracza ściśle pojęte funkcje zakładu; 3) wszechstronność prawa zakładowego pod względem funkcji i środków obejmuje przyznanie danej instytucji trzech kategorii uprawnień: a) prawo do tworzenia norm o charakterze ogólnym (statut i regulamin), b) prawo karania w zakresie dyscyplinarnym, włącznie z możliwością wydalenia z zakładu, c) prawo stosowania bezpośredniego przymusu; 4) jest skierowane do podmiotów, które aktualnie pozostają względem zakładu w szczególnym stosunku „podwładności, ale nie do innych osób - należy rozgraniczyć pojęcie prawa zakładowego od uprawnień zakładu chroniących instytucję od zewnątrz, zwanych »policją zakładową«"; 5) istnienie prawa zakładowego jest techniczną właściwością prawa administracyjnego - swoista sfera prawa publicznego. J.S. Langrod twierdził, że:

Ile razy więc państwo czy samorząd przedsiębiorą aktywność przyobleczoną w postać prawno-prywatną, tyle razy kończy się zasięg prawa zakładowego, a wchodzi w zastosowanie prawo cywilne, wzgl. prawo handlowe. Granica tych dwóch sfer prawnych aktywności zakładowej jest z natury rzeczy bardzo chwiejna w czasie i w przestrzeni, a co za tym idzie często trudno uchwytna ${ }^{48}$.

W doktrynie pojawiają się też wątpliwości, czy współcześnie nie zrezygnować z pojęcia władztwa zakładowego, czy nie należałoby pojęciu temu nadać nowego sensu, przyjmując, że w istocie chodzi o ,zakres władczych uprawnień organów zakładów administracyjnych"49, na które składają się: 1) kompetencje do załatwiania indywidualnych spraw w drodze wydawania aktów administracyjnych, na co wymagane jest odpowiednie umocowanie prawne; 2) stosowanie środków przymusu fizycznego, na co również potrzeba upoważnienia wynikającego z ustawy; 3) uprawnienia wynikające z ochrony prawa własności; 4) uprawnienia do określenia w regulaminie zakładowym: a) warunków dopuszczenia do świadczenia, b) przesłanek pozbawienia prawa do świadczenia na pewien okres albo na stałe, c) zasad zachowania się usługobiorcy w trakcie procesu świadczenia usługi. Paweł Chmielnicki twierdzi, że „Poza ostatnią kategorią nie widać żadnej różnicy pomiędzy uprawnieniami organów zakładów administracyjnych w stosunku do innych podmiotów korzystających z takich kompetencji, zarówno publicznych, jak i niepublicznych" 50 .

\footnotetext{
47 J.S. Langrod, op. cit., s. 394-397.

48 Ibidem, s. 397-398.

49 P. Chmielnicki, op. cit., s. 67.

50 Ibidem.
} 


\section{PRAWNE FORMY DZIAŁANIA ORGANÓW ZAKŁADU ADMINISTRACYJNEGO — WŁADZTWO ZAKŁADOWE W UJĘCIU ORZECZNICTWA SĄDOWEGO}

W orzecznictwie sądowym niejednokrotnie zwraca się uwagę na istotę władztwa zakładowego w sferze działania zakładów administracyjnych typu szkoły i placówki oświatowo-wychowawcze. Przyjmuje się, że szkoła wyższa jest zakładem administracyjnym, a więc jednostką organizacyjną, która nie jest organem państwowym ani organem samorządu, a która została powołana do wykonywania zadań publicznych i jest uprawniona do nawiązywania stosunków administracyjnoprawnych. Zakład administracyjny (publiczny), jako jedna z form decentralizacji, nie podlega władzy hierarchicznej organów administracji rządowej i sprawuje funkcje administracji publicznej samodzielnie, korzystając z władztwa zakładowego. Jego istota sprowadza się do możliwości jednostronnego kształtowania stosunków prawnych z użytkownikami zakładu, jak również z osobami, które znalazły się na jego terenie $w$ innym charakterze ${ }^{51}$. Przyjęto, że władztwo zakładowe jest częścią władztwa państwowego, przekazaną w drodze ustawy organom danego zakładu publicznego. W doktrynie podkreśla się, że zakłady administracyjne „nie tylko swoje istnienie wywodzą od państwa, ale i w swej działalności związane są ustawami państwowymi, jak i poddane są nadzorowi państwowemu"52. Nie budzi więc wątpliwości, że władztwo zakładowe powstaje $\mathrm{z}$ woli państwa i jest w stosunku do niego wtórne. Nie jest władztwem nieograniczonym, gdyż jego zakres zawsze jest wyznaczony przez przepisy prawa powszechnie obowiązującego ${ }^{53}$. Uregulowania zawarte w aktach wewnątrzzakładowych wiążą użytkowników zakładu, o ile są zgodne z przepisami powszechnie obowiązującymi, na podstawie których zostały podjęte (wyrok NSA z dnia 12 czerwca 2001 roku, I SA 2521/00). Władztwo zakładowe, jakim dysponują szkoły publiczne, uprawnia je do kształtowania w sposób jednostronny i władczy sytuacji prawnej użytkowników, na których rzecz usługi oświatowe są świadczone ${ }^{54}$.

WSA w Białymstoku w wyroku z dnia 15 lipca 2008 roku ${ }^{55}$ wyraźnie zaznacza, że władztwo zakładowe nie jest jakimś samoistnym władztwem państwowym, lecz częścią tego władztwa, wynikającą z upoważnienia organów zakładu do abstrakcyjnych, jak również konkretnych regulacji na podstawie i w ramach ustaw. Istotę władztwa zakładowego stanowi więc zakres upoważnień dla orga-

51 Por. uchwała NSA z dnia 13 października 2003 roku, sygn. OPS 5/03, ONSA 2004, nr 1, poz. 9.

52 E. Ochendowski, Prawo administracyjne. Część ogólna, Toruń 2004, s. 221.

53 T. Brzezicki, M. Masternak, Stanowienie norm ogólnych przez zakłady administracyjne, [w:] Podmioty administracji publicznej i prawne formy ich działania. Studia i materiaty z Konferencji Naukowej Poświęconej Jubileuszowi Profesora Eugeniusza Ochendowskiego, Toruń 2005, s. 77-78.

54 Wyrok NSA z dnia 25 kwietnia 2012 roku, I OSK 248/12, publ. LEX nr 1264738.

55 Sygn. akt II SA/Bk 320/08, LEX nr 566519; por. sygn. akt I OSK 3854/18 — Postanowienie NSA z dnia 14 listopada 2018 roku, publ. CBOSA. 
nów zakładu do jednostronnego kształtowania stosunków prawnych z użytkownikami zakładu (w szkole wyższej — ze studentami), jak również z osobami, które znalazły się na terenie zakładu w innym charakterze. W zakładzie administracyjnym proces realizacji zadań publicznych przebiega w obrębie szeroko pojętej jego organizacji. Wynika to $\mathrm{z}$ faktu, że grupa społeczna złożona $\mathrm{z}$ użytkowników zakładu administracyjnego ma zawsze (w danym przedziale czasu) charakter mniej lub bardziej zamknięty. Zgodnie z utrwalonym w nauce stanowiskiem nie wydaje się w drodze decyzji administracyjnych aktów organów uczelni ze sfery aktów administracyjnych wewnętrznych. Do takich aktów zaliczono w szczególności: zgodę dziekana wydziału na podjęcie dodatkowych studiów na innym kierunku tej samej bądź innej uczelni; odmowę udzielenia przez organy szkoły wyższej urlopu dziekańskiego studentowi; przyznanie, nieprzyznanie lub cofnięcie stypendium socjalnego studentowi; wystawienie określonej oceny z egzaminu; przeniesienie zajęć do innej sali; zasady zaliczenia przedmiotu przez nauczyciela. Wynika to z faktu, że jednostronne działania prawne organów zakładu skierowane na wywołanie konkretnych, indywidualnie oznaczonych skutków prawnych w ramach stosunku zakładowego, które nie wpływają na sam byt tego stosunku, nie wymagają wydawania decyzji indywidualnych, a co za tym idzie — nie podlegają reżimowi Kodeksu postępowania administracyjnego ${ }^{56}$ (dalej: kpa). Takie akty zakładowe wewnętrzne nie podlegają reżimowi kpa i nie są bezpośrednio zaskarżalne do sądu administracyjnego. Zaskarżeniu natomiast podlegają akty zakładowe zewnętrzne, czyli rozstrzygnięcia, które mają znaczenie dla praw i obowiązków studenta i przesądzają o nawiązaniu, odmowie nawiązania, przekształceniu bądź rozwiązaniu stosunku zakładowego ${ }^{57}$. Trzeba zauważyć, że procedura wydawania niektórych aktów wewnątrzzakładowych jest regulowana specjalnymi przepisami dotyczącymi między innymi postępowania dyscyplinarnego ${ }^{58}$.

Podobnie SN w uchwale z 18 grudnia 1992 roku $^{59}$ przyjął, że władztwo zakładowe przejawia się w rozstrzyganiu w sprawach dopuszczania do korzystania z usług zakładu, w określeniu obowiązków użytkowników oraz w możliwości pozbawienia użytkownika usług zakładu, jeżeli nie respektuje on zasad korzystania z tych usług. Czynności władcze są przy tym realizowane w trybie administracyjnym $\mathrm{z}$ wykorzystaniem $\mathrm{w}$ wielu przypadkach formy indywidualnego aktu administracyjnego, a także aktów o charakterze regulaminowym, obowiązujących w zakładzie. Korzystając z władztwa zakładowego, zakład administracyjny posługuje się różnymi formami działania — w relacjach zewnętrznych, dotyczących

56 E. Ochendowski, Zakład administracyjny jako podmiot administracji państwowej..., s. 214.

57 Sygn. akt IV SA/Wr 421/15 — Postanowienie WSA z dnia 25 września 2015 roku we Wrocławiu, publ. CBOSA; zob. L. Klat-Wertelecka, Organy szkoły wyższej w postępowaniu administracyjnym, [w:] Zarządzanie szkoła wyższa, red. J. Blicharz, A. Chrisidu-Budnik, A. Sus, Wrocław 2014, s. 123-131.

58 Zob. M. Wierzbowski, A. Wierzbowska, op. cit., s. 176.

59 Uchwała SN z 18 grudnia 1992 roku, sygn. III AZP 30/92, ONS 1993, nr 7-8, poz. 122. 
powstania i ustania stosunku zakładowego, działania powinny przyjąć formę indywidualnych aktów administracyjnych (decyzji), natomiast w sferze wewnątrzzakładowej zastosowanie powinny znaleźć akty generalne (statuty, regulaminy) ${ }^{60}$. W nauce zwraca się uwagę, że rozróżnienie aktów generalnych i indywidualnych nie jest ostre, gdyż w trakcie trwania stosunku administracyjnoprawnego mogą się pojawiać formy właściwe dla działań wewnętrznych, takie jak akt indywidualny, niewywołujący skutków na zewnątrz, a więc niewpływający na istotę stosunków łączących zakład z jego użytkownikiem ${ }^{61}$.

\section{WYGAŚNIĘCIE PRAWA DO KORZYSTANIA ZE ŚWIADCZEŃ ZAKŁADOWYCH JAKO PRZEJAW WŁADZTWA ZAKŁADOWEGO62}

Niewątpliwie specyfiką prawa administracyjnego jest to, że część źródeł tego prawa jest tworzona przez samą administrację ${ }^{63}$. Uprawnienia zakładu wobec użytkownika są określone z reguły ustawowo, szczegółowo zaś dookreślone w statucie lub regulaminach stanowionych przez organy zakładu. Dlatego też warto przyjrzeć się prawotwórstwu władz szkolnych. Do realizacji celów zakładu niezbędne jest władztwo zakładowe. Do realizacji celów zakładu będącego szkołą niezbędne jest podporządkowanie uczniów, wychowanków, studentów poleceniom kierownictwa, co może oznaczać, że cele szkoły określają granice władztwa zakładowego, poza które organy zakładu nie mogą wykroczyć. Ustawowe określenie stosunków szkoły z użytkownikiem wskazuje zwłaszcza, jakie działania mogą być stosowane wobec uczniów, wychowanków czy studentów ${ }^{64}$.

Szkoła publiczna, będąc zakładem administracyjnym, jest

podmiotem składającym się z wyodrębnionego majątku oraz osób, które przy użyciu tego majątku świadczą usługi oświaty, który to zakład zostaje utworzony na podstawie ustawy w celu realizacji zadań publicznych przy wykorzystaniu tzw. władztwa zakładowego. [...] władztwo zakładowe

60 Z. Czarnik, J. Posłuszny, op. cit., s. 490-491.

61 Zob. P. Daniel, Zakres sadowej kontroli decyzji podjętych w indywidualnych sprawach studentów i doktorantów, https://repozytorium.amu.edu.pl/bitstream/10593/17889/1/SPP_1_9_2015_ Pawel_Daniel.pdf (dostęp: 10.02.2020); szerzej zob. P. Dańczak, Decyzja administracyjna w indywidualnych sprawach studentów i doktorantów, Warszawa 2015.

62 Prawo do korzystania ze świadczeń zakładowych jest przejściowe. Z różnych przyczyn prawo to może wygasnąć, na przykład: osiągnięcie przez użytkownika celu, dla którego stał się użytkownikiem; rezygnacja z korzystania ze świadczeń zakładowych, gdy korzystanie to było dobrowolne; zwolnienie z zakładu, gdy korzystanie z niego było obowiązkowe; skreślenie z listy użytkowników (na przykład w wyniku zastosowania kary dyscyplinarnej); z powodu likwidacji zakładu i wskutek śmierci użytkownika.

${ }^{63}$ M. Kotulski, Prawo administracyjne a prawo karne, [w:] Teoria instytucji prawa administracyjnego..., s. 681.

${ }^{64}$ Zob. M. Wierzbowski, A. Wierzbowska, op. cit., s. 176. 
jest częścią władztwa państwowego, przekazaną w drodze ustawy organom danego zakładu publicznego. [...] organy te są uprawnione do podejmowania konkretnych regulacji na podstawie i w ramach ustaw. [...] uregulowania zawarte w aktach wewnątrzzakładowych wiążą użytkowników zakładu, o ile są zgodne z przepisami powszechnie obowiązującymi, na podstawie których zostały podjęte (wyrok NSA z 12 czerwca 2001, I SA 2521/00) ${ }^{65}$. Władztwo zakładowe jakimi dysponują szkoły publiczne uprawnia je do kształtowania w sposób jednostronny i władczy sytuacji prawnej użytkowników ${ }^{66}$.

NSA w wyroku z dnia 19 października 2016 roku podkreśla: „Ze specyfiki uczelni wyższych jako zakładów administracyjnych wynika, że jeśli jednostka wyraża chęć wstąpienia w poczet destynatariuszy takiego zakładu, to musi wyrazić zgodę na przestrzeganie przepisów wewnętrznych (uchwał, regulaminów) obowiązujących w tym zakładzie, czyli dostosować się do reguł w nim panujących"67. W doktrynie w przypadku prawotwórstwa organów szkoły wyższej można zauważyć wydzielenie trzech kategorii stanowionych aktów prawnych ${ }^{68}$ : 1) akty regulujące stosunki pracownicze, w tym regulaminy organizacyjne normujące strukturę organizacyjną uczelni, regulamin pracy; 2) akty regulujące stosunki zakładowe — stosunki wiążące użytkowników uczelni z uczelnią ujmowaną jako zakład administracyjny (akty normujące organizację i tok procesu kształcenia oraz prawa i obowiązki studentów i innych destynatariuszy uczelni, w tym regulaminy studiów, programy studiów, studiów podyplomowych i kształcenia specjalistycznego, programy kształcenia w szkołach doktorskich); 3) akty regulujące stosunki zewnętrzne, to znaczy stosunki administracyjnoprawne objęte władztwem publicznym wykraczające poza obszar władztwa zakładowego, w tym stosunki związane z załatwianiem indywidualnych spraw z zakresu administracji publicznej (na przykład w sprawach skreślenia z listy studentów czy w sprawach przyznania świadczeń pomocy społecznej). Do tej ostatniej grupy aktów można zaliczyć między innymi uchwały senatu w sprawie przeprowadzenia rekrutacji na uczelni — warunki, tryb, terminy rozpoczęcia i zakończenia, sposób jej przeprowadzenia; regulaminy studiów w części określenia przesłanek skreślenia z listy studentów czy wznawiania studiów; statut uczelni jako akt o fundamentalnym znaczeniu dla organizacji i zasad jej funkcjonowania, zawierający przepisy należące do wszystkich trzech spośród wskazanych wyżej kategorii.

Ustawodawca określił zamknięty katalog przesłanek skreślenia z listy studentów. Student podlega skreśleniu z listy studentów w przypadku: ,1) niepodjęcia studiów; 2) rezygnacji ze studiów; 3) niezłożenia w terminie pracy dyplomowej lub egzaminu dyplomowego; 4) ukarania karą dyscyplinarną wydalenia z uczel-

${ }^{65}$ LEX nr 54756.

66 Wyrok NSA w Warszawie z dnia 25 kwietnia 2012 roku, I OSK 248/12, LEX nr 1264738; zob. http://orzeczenia.nsa.gov.pl/doc/60C64AF354 (dostęp: 30.09.2019).

67 I OSK 302/16, LEX nr 2168069.

68 P. Wilczyński, Szkolnictwo wyższe, [w:] Prawo administracyjne materialne, red. Z. Duniewska et al., Warszawa 2020, s. 563-564. 
ni”. Fakultatywny charakter ma skreślenie studenta z listy studentów w przypadku: „1) stwierdzenia braku udziału w obowiązkowych zajęciach; 2) stwierdzenia braku postępów w nauce; 3 ) nieuzyskania zaliczenia semestru lub roku w określonym terminie; 4) niewniesienia opłat związanych z odbywaniem studiów" ${ }^{\prime 69}$. W ramach działalności prawotwórczej organów uczelni regulamin studiów dookreśla przesłanki materialne rozstrzygnięć $\mathrm{w}$ indywidualnych sprawach, o których stanowi ustawa. Zgodnie $\mathrm{z}$ regulaminem studiów dziekan skreśla studenta $\mathrm{z}$ listy studentów w przypadku: „1) rezygnacji ze studiów złożonej w postaci pisemnej. Rezygnację uznaje się za złożoną z datą wpłynięcia pisma do dziekanatu; 2) niezłożenia w terminie pracy dyplomowej lub egzaminu dyplomowego; 3) ukarania karą dyscyplinarną wydalenia z Uczelni”. Fakultatywny zaś charakter ma skreślenie studenta w przypadku:

1) stwierdzenia braku postępów w nauce; 2) nieuzyskania zaliczenia semestru lub roku; 3) niewniesienia opłat związanych z odbywaniem studiów; 4) stwierdzenia braku udziału w obowiązkowych zajęciach. Za brak udziału w zajęciach uważa się nieusprawiedliwioną nieobecność na zajęciach w wymiarze przekraczającym możliwości odrobienia, na podstawie pisemnej informacji od prowadzących poszczególne zajęcia ${ }^{70}$.

Decyzje w sprawie skreślenia z listy studentów, odmawiające zwolnienia z opłat, reaktywacji na studia, wznowienia studiów albo przeniesienia z innej uczelni, podejmowane są w reżimie kpa.

Przedstawione rozważania mimo upływu czasu nadal pozostają cenne dla rozwoju teorii i praktyki tworzenia źródeł prawa zakładowego i stosowania władztwa zakładowego, kształtując w ten sposób sytuację prawną użytkownika na terenie danego zakładu.

\title{
SELECTED SOURCES OF ADMINISTRATIVE ESTABLISHMENTS' LAW AND THE ROLE OF THE ESTABLISHMENT'S POWER IN RELATION TO THE ADMINISTRATIVE ESTABLISHMENT USER
}

\author{
Summary
}

The article presents the evolution of the concept of the establishment's power and sources of administrative establishments' law in the field of activity of the administrative establishment. The aim of the article is to explain what legal forms of public administration activity determine the legal situation of the administrative establishment user in the field of school activity. The subject matter of the article is divided into three parts: 1) reinterpretation of the concept of the establishment's power

${ }^{69}$ Zgodnie z art. 108 ustawy z dnia 20 lipca 2018 roku Prawo o szkolnictwie wyższym i nauce (tekst jedn. Dz.U. z 2020 r. poz. 85 z późn. zm.).

70 Zgodnie z § 41 ust. 1 regulaminu studiów - uchwała Nr 94/2019 Senatu Uniwersytetu Wrocławskiego z dnia 22 maja 2019 roku w sprawie regulaminu studiów w Uniwersytecie Wrocławskim. 
in the doctrine of administrative law and in the judiciary; 2) legal forms of public administration activity and the establishment's power in the field of a school's activity; 3) expiration of the right to use administrative the establishment's benefits as a manifestation of the establishment's power.

Keywords: administrative establishment, sources of law, establishment's power

\section{BIBLIOGRAFIA}

Bednarczyk A., Zależność zakładowa, [w:] Prawo administracyjne w mechanizmie prawa, red. J. Filipek, Kraków 2012.

Bigo T., Związki publiczno-prawne w świetle ustawodawstwa polskiego, Warszawa 1928.

Brzezicki T., Chudziński B., Aktualność koncepcji „prawa zakładowego” na przykładzie szkoły wyższej, [w:] Teoria instytucji prawa administracyjnego. Ksiega pamiatkowa Profesora Jerzego Stefana Langroda, red. J. Niczyporuk, Paryż-Lublin 2011.

Brzezicki T., Masternak M., Stanowienie norm ogólnych przez zakłady administracyjne, [w:] Podmioty administracji publicznej i prawne formy ich działania. Studia i materiały z Konferencji Naukowej Poświęconej Jubileuszowi Profesora Eugeniusza Ochendowskiego, Torun 2005.

Chmielnicki P., Zakłady administracyjne w Polsce. Ustrój wewnętrzny, Warszawa 2008.

Czarnik Z., Posłuszny J., Zakład publiczny, [w:] System prawa administracyjnego. Podmioty administrujace, red. R. Hauser, Z. Niewiadomski, A. Wróbel, t. 6, Warszawa 2011.

Dańczak P., Decyzja administracyjna w indywidualnych sprawach studentów i doktorantów, Warszawa 2015.

Filipek J., Prawo administracyjne. Instytucje ogólne, cz. 1, Kraków 1995.

Homplewicz J., Polskie prawo szkolne. Zagadnienia podstawowe, Warszawa 1984.

Homplewicz J., Prawne formy działania władz szkolnych, „Chowanna” 1972, z. 1.

Homplewicz J., Szkoły i placówki oświatowo-wychowawcze w systemie administracji państwowej, „Zeszyty Naukowe UJ. Prace Prawnicze” 1966, z. 25.

Homplewicz J., Tradycyjne a wspótczesne instytucje prawa szkolnego (Studium z zakresu nauki prawa administracyjnego), „Zeszyty Naukowe UJ. Prace Prawnicze” 1985, z. 112.

Homplewicz J., Zagadnienia prawne działalności opiekuńczo-wychowawczej, Rzeszów 1989.

Homplewicz J., Zagadnienia ustawodawstwa szkolnego (Zarys problematyki polskiego prawa szkolnego), Katowice 1973.

Izdebski H., Kulesza M., Administracja publiczna. Zagadnienia ogólne, wyd. 2, Warszawa 1999.

Klat-Wertelecka L., Organy szkoły wyższej w postępowaniu administracyjnym, [w:] Zarządzanie szkoła wyższa, red. J. Blicharz, A. Chrisidu-Budnik, A. Sus, Wrocław 2014.

Klonowski K., Ochrona praw użytkownika zaktadu publicznego, [w:] Instytucje wspótczesnego prawa administracyjnego. Księga jubileuszowa Profesora zw. dra hab. Józefa Filipka, red. I. Skrzydło-Niżnik et al., Kraków 2001.

Klonowski K., Władztwo zakładowe, [w:] Władztwo administracyjne. Administracja publiczna w sferze imperium $i$ w sferze dominium, red. J. Łukaszewicz, Rzeszów 2012.

Kotulski M., Prawo administracyjne a prawo karne, [w:] Teoria instytucji prawa administracyjnego. Ksiega pamiatkowa Profesora Jerzego Stefana Langroda, red. J. Niczyporuk, Paryż-Lublin 2011.

Langrod J.S., Instytucje prawa administracyjnego. Zarys części ogólnej. Reprint, Kraków 2003.

Lisowski P., Prawo zaktadowe - in rebus angustis? (wybrane problemy administracyjnoprawne), „Przegląd Prawa i Administracji” C/1, 2015.

Lisowski P., Relacje strukturalne w polskim samorzadzie terytorialnym, Wrocław 2013.

Lisowski P., Szkoła samorzadowa jako zaktad administracyjny, Wrocław 1997 (niepubl.). 
Lisowski P., Z problematyki postępowania administracyjnego na forum szkoły samorzadowej, [w:] Nauka administracji wobec wyzwań wspótczesnego państwa prawa, red. J. Łukaszewicz, Rzeszów 2002.

Ochendowski E., Koncepcja szczególnych stosunków władczych i jej rola, [w:] Studia z dziedziny prawa administracyjnego, red. L. Bar, Wrocław 1971.

Ochendowski E., Organy administracji niezespolonej i zakłady administracyjne, [w:] System prawa administracyjnego, t. 2, red. J. Jendrośka, Wrocław 1977.

Ochendowski E., Prawo administracyjne. Część ogólna, Torun 2001.

Ochendowski E., Zakład administracyjny jako podmiot administracji państwowej, Poznań 1969.

Prawo administracyjne, red. J. Boć, Wrocław 2007.

Przybysz P., Sytuacja prawna jednostki w zaktadzie oświatowym, [w:] Jednostka wobec działań administracji publicznej, red. E. Ura, Rzeszów 2001.

Raszewska-Skałecka R., Koncepcja zakładu administracyjnego w polskiej nauce prawa administracyjnego, „Przegląd Prawa i Administracji” 68, 2005.

Raszewska-Skałecka R., Miejsce statutu i regulaminu zakładu administracyjnego w systemie źródeł prawa. Kwestie prawne, „Przegląd Prawa i Administracji” 77, 2008.

Raszewska-Skałecka R., Statut i regulamin zakładu administracyjnego jako źródła prawa, Wrocław 2007.

Wierzbowski M., Wierzbowska A., Zakład administracyjny, [w:] Prawo administracyjne, red. J. Jagielski, M. Wierzbowski, Warszawa 2019.

Wilczyński P., Szkolnictwo wyższe, [w:] Prawo administracyjne materialne, red. Z. Duniewska et al., Warszawa 2020.

Zimmermann J., Prawo administracyjne, Warszawa 2018. 